\title{
Department of Environmental Analyses, Geological Mapping and Economic Geology
}

\author{
Jacek Matyszkiewicz, Maciej Kotarba, Mariusz Krzak, Marek Wendorff
}

\section{INTRODUCTION}

Department of Environmental Analyses, Geological Mapping and Economic Geology (KAŚKGG) is a continuation of activities of several former departments and laboratories. One of these was the Laboratory of Geological Mapping initiated in 1952, at the time when the Faculty of Geology and Exploration became an individual unit, separated from the Faculty of Mining and Surveying. Prof. Walery Goetel became the Head of the new Geology Department, which was an association of a.o. former Department of General Geology II renamed to the Laboratory of Geological Mapping headed by Henryk Świdziński.

As a result of another reorganisation of the Faculty, which coincided with the passing away of H. Świdziński, Institut of Regional Geology and Coal Deposits was instituted, which incorporated the Laboratory of Tectonics and Geological Mapping with Kazimierz Bogacz as its Head. In the course of still another reorganization (in 1974) of the new Institute of Geology and Mineral Resources this unit returned to the previous name of the Laboratory of Geological Mapping, with $\mathrm{K}$. Bogacz continuing as the Head.

Upon the death of K. Bogacz, Jacek Rutkowski became its new Head. Professor Rutkowski continued until 1989 when this position was taken over by Aleksandra Kostecka, who headed the Department until her death. In 1999 Jacek Matyszkiewicz became new Head of Department.

Upon still another reorganisation in 2006 the Department of Geological Mapping evolved into Department of Environmental Analyses, Geological Mapping and Economic Geology (KAŚKGG). The name change was justified by a significant change and broadening of the departmental staff numbers and scientific activities by research teams of Professors: Maciej Kotarba, Andrzej Paulo and Marek Krąpiec. The following autonomous units, ranked as Laboratories, are now a part of the KAŚKGG structure: Geological Mapping, Hydrocarbons Geochemistry, Environmental Analyses, and Economic Geology and Resources Protection.

\section{RESEARCH ACTIVITIES}

\section{Laboratory of Geological Mapping}

Stratigraphy of the Carpathian Flysch successions and tectonics of the Outer Carpathians were the predomnant themes of research activities at an early stage, during Henryk Świdziński headship. This trend was initially followed by the team of $\mathrm{K}$. Bogacz but, with the passage of time, interests in geological structure, especially tectonics, of the $S$ part of the Kraków Upland prevailed. The concept of bloc tectonics of the Carpathian Foreland within the boundary zone between the Carpathian Foredeep and the Kraków Upland, dating to that period, as well as a model of the Palaeozoic fault tectonics of the Kraków region are valid until now. K. Bogacz also co-authored a hypothesis of hydrothermal karst origins of the Upper-Silesian lead and zinc ore deposits.

In the 80th and 90th research work on the geological structure of the Kraków region was continued, and in a sense, the results were summarized in the Sheet Kraków of the 1:50 000 Detailed Geological Map of Poland. Research into lithology, sedimentary environments and diagenesis of the Upper Jurassic limestones of the Kraków-Częstochowa Upland and southern Germany, are now continued by J. Matyszkiewicz, Marcin Krajewski, Ireneusz Felisiak, Alicja Kochman i Piotr Olchowy. 
Also research on precipitation of carbonates out of mineral waters in the Carpathians of Poland and Slovakia, conducted in the past by A. Kostecka, is being continued. Stratigraphy and tectonics of the basement strata underlying the brown coal deposit at Bełchatów are researched by I. Felisiak, Ewa Szewczyk, J. Matyszkiewicz, M. Krajewski and P. Olchowy. Work on lithology and stratigraphy of the Quaternary deposits and the geomorphological evolution of selected areas, esp. the Kraków region and the $\mathrm{W}$ part of the Sandomierz Basin, has been done by J. Rutkowski and T. Sokołowski. Comprehensive studies on history of the Wigry Lake conducted by a multidysciplinary team coordinated by J. Rutkowski and Katarzyna Król were another significant achievement.

Recently conducted projects continue the investigations into lithology and tectonics of the Late Jurassic carbonate rocks. Next to the Kraków-Częstochowa Upland region, which is the area of work of most staff members, such research has been also conducted in the past years in the Crimea Mountains (M. Krajewski) and N Italy (J. Matyszkiewicz, A. Kochman, P. Olchowy). Research into the Late Cretaceous carbonate strata of the Miechów Basin was started by Agata Jurkowska, and the depositional environment of the Zechstein Main Dolomite in the W part of Poland has been studied by M. Krajewski. Conditions of deposition of the Miocene sulphur-bearing limestones of the Osiek deposit were reconstructed (P. Olchowy). Important results have been obtained in the course of research conducted by Jerzy Zasadni and Andrzej Świąder into the development of glaciers during the last glacial maximum in the Tatra Mountains and selected regions of the Alps. A part of this work culminated in the publication of a map depicting the extent of glaciers in the Tatra Mountains, which won international applause and an award. On the other hand, a part of the maps published in the English version of Atlas of the Tatra National Park were collated. Furthermore, geomorphological and geological conditions of preservation of macrofossils from a famous palaeontological site at Starunia were explained by Janusz Olszak and Tadeusz Sokołowski. T. Sokołowski was involved in geoarchaeological activities in the Kraków area. Other investigations conducted by the Laboratory staff include evolution and stratigraphy of river terraces and influence of young tectonic movements on their origin (J. Olszak) as well as dendrochronological work in the Carpathians (Małgorzata Danek). A summary study devoted to the neotectonic stage of evolution of the Carpathians and their foredeep was published by Witold Zuchiewicz.

Marek Wendorff, conducted research in the Outer Carpathians on olistostromes, and sedimentology, basin analysis and diagenesis of the Cergowa Beds. His studies of Neoproterozoic successions in Central and SW Africa significantly expanded the knowledge of these regions, famous for their world-class ore deposits. Work on "the Katangan megabreccias" and Neoproterozoic glacial sediments in the Central African Copperbelt resulted in revision of stratigraphy, a new model of tectonic evolution, syntectonic sedimentation and tectonostratigraphy of allochthonous orebodies; it has also advanced a new outlook of the 'Snowball Earth' concept. These results stemmed from the period when he was the initiator and International Leader of two 5-year regional projects of UNESCO (IGCP 302 and IGCP 419 with over 80 participants - geologists from 18 countries) devoted to the Neoproterozoic successions, sedimentary basins, tectonics and ore deposits in Central-toSW Africa and S America. M. Wendorff also studied meteorite impact crater "Jwaneng South" in the Kalahari Desert and published a novel model of impactogenic structure infill upon granitic basement. He is also a member of an international research team, which recently discovered platinum-group mineralization in the Neoproterozoic Kalahari Copperbelt succession in Botswana.

\section{Laboratory of Petroleum Geochemistry and Environmental Analyses}

A research team of Maciej Kotarba developed a programme that focused on petroleum geochemistry and environmental analyses with applications of isotope and geochemical analytical techniques. The scientific results of the team have broadened the foundations of petroleum geochemistry and are devoted to the conditions controlling the origins and migration of hydrocarbons in sedimentary basins in the territory of Poland. This research is of fundamental importance for deposit exploration and assessment and 
has appeared important for environmental protection because it has revealed accumulations of gaseous hydrocarbons near the soil surface, which pose hazard to human life.

In the periods 2004-2005 and 2006-2009 the team started interdisciplinary investigations in the Starunia region (E Carpathians) to identify sites prospective for potential occurrences of the hairy rhinoceros remains in the Quaternary sediments. This was a continuation of an earlier work of polish palaeontologists who in 1907 and 1929 discovered in the Pleistocene deposits well preserved remains of mammoth and hairy rhinoceros, including a unique, almost complete specimen of the latter.

\section{Laboratory of Economic Geology and Deposits Protection}

A team of Andrzej Paulo, which after his retirement is headed by Mariusz Krzak, was initially focused on ore deposits, deposits of barite and fluorite, and regional metallogenic syntheses. Two textbooks represent important achievements of this team; they have been authored by Henryk Gruszczyk: Science of deposits and Methods of exploration of mineral deposits. The thrust of work, which is continued, covers petrological and economic investigations of volcanogenic formations. Since the 80th Economic Geology remains an individual research branch that includes the problems of prognostics and prospecting for deposits, raw materials policy, resource management and deposit valuation, possibilities and economic feasibility of their development, valuation of ores and concentrates, management of raw and waste materials and applied approaches to deposit protection. The related research problems were presented in the following textbooks: Economic Geology (H. Gruszczyk 1989), Outline of mineral resources management (A. Bolewski, H. Gruszczyk, E. Gruszczyk 1990) and Protection of natural environment and mineral resources (A. Paulo, ed. 1995). Problems of economic geology were published in a 16-volume series "Mineral deposits of the World" (1976-1987). Since the 1990s the research range has been broadened by inclusion of environmental management problems and environmental protection, geosozological determinants, geological-economic maps, application of
GIS tools to the decision making process, assessment of influence of mining and processing units on the environment, and management of former mining areas. Applications of mathematical methods in economic geology, economic assessment of raw material-related projects and geoenvironmental mapping are important other fields of research.

\section{Equipment}

Considering the departmental equipment, the most important are the items kept in the Faculty Lab of Organic Geochemistry, which works especially for the Laboratory of Petroleum Geochemistry and Environmental Analysis. It is now one of the best such laboratories in the World with the highest quality equipment with which extensive analyses, experiments as well as organic geochemical and environmental studies can be conducted. This is a leading facility in Poland with 31 major items of research equipment at its disposal. Among the most important are: Delsi Rock-Eval 2 (screening pyrolysis of rock: TOC, kerogen type, maturity and hydrocarbon potential), Vinci Technologies Rock-Eval 6 Turbo (screening pyrolysis of rock, soil, coal, etc.: TOC, kerogen type, maturity and hydrocarbon potential, and mineral carbon content), Tecator Soxtec AVANTI 2055 and Soxhlet extractors (bitumen extraction), Vinci Technologies Kerogenatron (separation of kerogen), Carlo Erba EA 1108 elemental analyser (elemental analysis of coal/kerogen/bitumen/oil), Parr high pressure oxygen vessel (preparation of sulphur compounds for $\delta^{34} S$ analysis), Anton Paar DMA 4500M density meter (density of oil and other liquids), Hewlett Packard 5890 Series II GC with FID and TCD and Agilent 7890A GC with FID and TCD (molecular composition of hydrocarbon $\left[\mathrm{CH}_{4}, \mathrm{C}_{2} \mathrm{H}_{6}, \mathrm{C}_{3} \mathrm{H}_{8}, i \mathrm{C}_{4}\right.$, $n \mathrm{C}_{4}, i \mathrm{C}_{4}, n \mathrm{C}_{5}$, neo- $\mathrm{C}_{5}, \mathrm{C}_{6}$ ] and non-hydrocarbon components $\left[\mathrm{N}_{2}, \mathrm{O}_{2}, \mathrm{Ar}, \mathrm{He}, \mathrm{CO}_{2}, \mathrm{H}_{2}, \mathrm{H}_{2} \mathrm{~S}\right]$, Hewlett Packard 5890 series II GC (GC-FID) (whole bitumen and oil GC analysis), Agilent 7890A GC with 5975C MSD (GC-MS) (biomarkers determination), Agilent 7990A GC with triple quadropole QQQ detector (GC-MS-MS) (biomarkers determination), Agilent 7890A GC with pyrolyser and 5975C MSD (Py-GC/MS) (structure of kerogen determination), Finnigan Delta Plus mass spectrometer (IRMS) connected with Hewlett Packard 6890 series II GC and Carlo Erba EA1108 elemental analyser (stable 
carbon, nitrogen and sulphur isotope analyses of gaseous, liquid and solid samples), Finnigan Delta V Plus mass spectrometer (IRMS) connected with Thermo GC and elemental analyser (stable carbon, hydrogen, oxygen, nitrogen and sulphur isotope analyses of gaseous, liquid and solid micro-samples). The main purposes of organic geochemical analyses are the determination and/or evaluation of the organic matter content and its genetic type, maturity and hydrocarbon potential; genetic type of oil, and influence of secondary processes; oil-oil and source rock-oil genetic correlations; genetic types of natural gas, shale gas, coal-bed methane gas, tight gas, greenhouse gases and proportion of mixing between microbial and thermogenic gases.

Moreover, the only European installation for hydrous pyrolysis (HP) experiments has been construed at the Laboratory at the end of 2012 with the aid of Dr. M.D. Lewan from U.S. Geological Survey in Denver - the pioneer of this geochemical method. HP simulates natural coalification processes better than both closed- and open-system anhydrous pyrolysis because water is always present in geological systems. The results of HP experiments are also used for evaluation of kinetic parameters of kerogen. These parameters are very useful for 1-D, 2-D and 3-D modelling of petroleum processes and systems. In our Laboratory we have software for basin analysis and modelling of processes and systems: PetroMod 1-D, PetroMod 2-D, PetroMod 3-D an PetroRisk (Schlumberger), and BasinMod 1-D, BasinMod 2-D, BasinMod 3-D, Model Viewer and BasinFlow (Platte River Asc. Inc.).

\section{EDUCATIONAL OFFER}

\section{Laboratory of Geological Mapping}

"Geological mapping" is our leading course, which consists of lectures, practicals, and field classes conducted in Poland and abroad, e.g. in Russia, Croatia, Slovakia, Germany, Ukraine, and even in Vietnam and Ecuador. Other compulsory courses are: "Geomorphology and Quaternary geology" and a part of "Sedimentology". Among the elective courses, some appear especially popular among students who like trips and activities in the field. These are: "Reefs and other carbonate buildups", "Karst and speleology", "The Tatra Mountains - geology, geomorphology and protection",
"Geology of the Flysch Carpathians", "Geohazards", "Structural geology", and also "Geotectonics", which is conducted in English. Courses given to "Geological mapping" students include: "GIS methods in geological mapping", "Computing as a support to geological mapping", "Teledetection in geological mapping", "Analysis of geological maps and cross sections" and "Geology and mapping of landslides". In addition, one of our staff members teaches several courses given exclusively in English to other specialisations - "Geological English", "World geology - for economic geology MSc programme" "Scientific writing"; "Sedimentology" for foreign students and "Monograph lectures" and "English in earth sciences" to $\mathrm{PhD}$ students.

\section{Laboratory of Petroleum Geochemistry and Environmental Analyses}

The teaching staff of this Laboratory conduct educational activities related to geology of oil and gas, but the main educational effort is focused on courses within the specialization "Engineering of balanced development" in the field of "Environemtal engineering". It should be stressed that this specialisation is elected mainly by students from the Ukrainian State Technical Institute for Petroleum and Gas in Ivano-Frankivsk, who study at our Faculty in the framework of educational exchange and scientific cooperation.

\section{Laboratory of Economic Geology and Deposits Protection}

Courses given by this unit are related to geology of mineral deposits, economic geology, management of mineral resources, protection of mineral deposits, environmental management, volcanology, environmental impact assessment, environmental management, metals markets, and environmental mapping. In the period 2001-2006 a new specialization: "Management of the geological environment" has been established as the only such specialty in Poland. Between 1992 and 2003 the team organized and gave postgraduate courses in the programme "Protection of natural environment and mineral resources". This programme has been considered as a model for other countries of Central and Eastern Europe and was supported by PHARE/TESSA programme. 


\section{COOPERATION}

\section{Laboratory of Geological Mapping}

Research and educational cooperation of the Laboratory team with foreign units (mainly in Germany, Romania, Switzerland) which resulted in many joint publications. In the period 2004-2012 we co-organised Joint Master Course "Carbonate Rocks" in collaboration of Friedrich-Alexander Universität, Erlangen-Nürnberg and Babeş-Bolyai University, Cluj-Napoca. On the other hand, young staff members and $\mathrm{PhD}$ students visited academic institutions abroad on scientific attachemnts (A. Kochman - Vietnam Academy of Science and Technology, Institut of Geophysics, Hanoi, 2011) and grants (M. Danek - Department of Geography Memorial University of Newfoundland, 2014-2015; E. Opyrchał - Eidegenössische Technische Hochschule Zürich ETH Zürich, Department of Physics, Institute for Particle Physics, 2016-2017). Special mention is deserved by long-standing cooperation of J. Zasadni with Austrian Geologische Bundesanstalt in the framework of geological mapping of the Alps. At the same time, he conducts a vigorous research programme with ETH Zürich focused on glaciations in the Alps and Western Catpathians. $\mathrm{M}$. Wendorff has been continuing his research involvement in Central and SW Africa cooperating with the University of the Witwatersrand (Johannesburg, RSA), University of Botswana and exploration Companies from Australia and Africa. $\mathrm{He}$ was also active in the framework of UNESCO-Poland UNESCO/Poland Co-sponsored Fellowship Programme in Engineering (2011-2014). As part of this activity he supervised fieldwork in Botswana and then co-supervised laboratory work in Poland of a Botswana MSc student, who defended his thesis at our Faculty with distinction. He also prepared a programme of attachment and co-supervised two other Fellows visiting AGH UST under the same programme.

\section{Laboratory of Petroleum Geochemistry and Environmental Analyses}

Research staff of the Laboratory has cooperated with foreign scientific institutions, e.g., U.S. Geological Survey in Denver, USA; Geochemical Research Center, University of Tokyo, Japan; Institut Francais du Petrole in Rueil Malmaison, France; Institute of Geology, Universität Claushal, Germany; Ivano-Frankivsk National Technical University of Oil and Gas, Ivano-Frankivsk, Ukraine; National Academy of Sciences of Ukraine, Institute of Geology and Geochemistry of Combustible Minerals, Lviv, Ukraine.

\section{Laboratory of Economic Geology and Deposits Protection}

This Laboratory cooperates with scientists from Chile (University at La Serena), Turkey (Ankara University) and Spain (Oviedo University). Since 2003 our scientists have been participating in recurrent Polish Research Expeditions to Peru with the aim of establishing National Parks: Colca Canyon and Volcanoes Valley. During this activity cooperation was established with a.o. State University San Agustin (UNSA) w Arequipa, Catholic University Santa Maria (UCSM) at Arequipa and Geological-Mining Institute INGEMMET) at Lima. In the period 2012-2013 S. Gałaś coordinated an international project in the framework of Wisegrad Fund, which involved cooperation of: AGH UST Faculty of Geology, Geophysics and Environmental Protection, Technical University of Košice (Slovakia), Mendel University in Brno (the Czech Republik) and the Hungarian Biological Society. 